\title{
Novosphingobium nitrogenifigens sp. nov., a polyhydroxyalkanoate-accumulating diazotroph isolated from a New Zealand pulp and paper wastewater
}

Correspondence

Sarah Addison

sarah.addison@

scionresearch.com

\author{
Sarah L. Addison, Sonia M. Foote, Nicola M. Reid and Gareth Lloyd-Jones \\ Eco-Smart Technologies Group, Scion, Rotorua, New Zealand
}

\begin{abstract}
A diazotroph capable of accumulating significant amounts of polyhydroxyalkanoate was isolated in New Zealand from a bioreactor treating nitrogen-deficient pulp and paper-mill effluent. Strain $Y 88^{\top}$ is Gram-negative, rod-shaped and positive for catalase, nitrate reductase and urease activities. The complete $16 \mathrm{~S}$ rRNA gene sequence was most similar to those of other members of the genus Novosphingobium, the highest level of similarity $(94.7 \%)$ being found with respect to the type strain of Novosphingobium stygium. The combined phenotypic, chemotaxonomic and sequence data show that while strain $Y 88^{\top}$ belongs to the genus Novosphingobium, it is distinct from all currently recognized Novosphingobium species. Therefore, strain $\mathrm{Y}^{8} 8^{\top}$ represents the first nitrogen-fixing species of the genus Novosphingobium, for which the name Novosphingobium nitrogenifigens sp. nov. is proposed. The type strain is Y $88^{\top}\left(=\right.$ ICMP $16470^{\top}=$ DSM $\left.19370^{\top}\right)$.
\end{abstract}

The genus Sphingomonas was described by Yabuuchi et al. (1990) as comprising strictly aerobic, chemoheterotrophic, yellow-pigmented, Gram-negative, rod-shaped bacteria containing glycosphingolipids as cell-envelope components - a classification that does not take into account heterogeneity in polyamine patterns (Busse \& Auling, 1988). Takeuchi et al. (1994) divided the group into four clusters on the basis of the 16S rRNA gene sequences, subsequently combining phylogenetic, chemotaxonomic and physiological analyses to divide the genus into the genera Sphingomonas, Sphingobium, Novosphingobium and Sphingopyxis (Takeuchi et al., 2001). Although Yabuuchi et al. (2002) suggested that the genus Sphingomonas should remain undivided, the genus Novosphingobium as proposed by Takeuchi et al. (2001) has been accepted by many 'sphingomonad' taxonomists (Kämpfer et al., 2002; Tiirola et al., 2005; Liu et al., 2005) because of the clear separation of Novosphingobium from the genus Sphingomonas sensu stricto demonstrated in phylogenetic and chemotaxonomic studies. The genus Novosphingobium includes a diverse group of bacteria displaying a number of unique traits that enable them to inhabit a variety of soil, sediment and aquatic environments. At the time of writing the genus

The GenBank/EMBL/DDBJ accession numbers for the 16S rRNA gene sequence and the nifH gene sequence of strain $\mathrm{Y}^{\circ} 8^{\top}$ are DQ448852 and D0660368, respectively.

A transmission electron micrograph of $\mathrm{Y} 88^{\top}$ cells containing polyhydroxyalkanoate granules is available as a supplementary figure with the online version of this paper.
Novosphingobium included 11 species: Novosphingobium aromaticivorans (Balkwill et al., 1997), Novosphingobium capsulatum (Leifson, 1962; Yabuuchi et al., 1990), Novosphingobium hassiacum (Kämpfer et al., 2002), Novosphingobium lentum (Tiirola et al., 2005), Novosphingobium pentaromativorans (Sohn et al., 2004), Novosphingobium rosa (Takeuchi et al., 1995), Novosphingobium stygium (Balkwill et al., 1997), Novosphingobium subarcticum (Nohynek et al., 1996), Novosphingobium subterraneum (Balkwill et al., 1997), Novosphingobium taihuense (Liu et al., 2005) and Novosphingobium tardaugens (Fujii et al., 2003).

We have isolated a bacterial strain from New Zealand pulp and paper-mill effluents (C/N ratio of $140: 1)$ undergoing biological treatment in a bioreactor operated under nitrogen-limited conditions. The strain, designated $\mathrm{Y}^{8} 8^{\mathrm{T}}$, was isolated at $30{ }^{\circ} \mathrm{C}$ on nutrient agar (containing, $1^{-1}$, $15 \mathrm{~g}$ purified agar, $3.0 \mathrm{~g}$ beef extract and $5.0 \mathrm{~g}$ peptone) with $5 \mathrm{mM} \mathrm{NiCl}_{2}$. The cells were Gram-negative, aerobic, non-spore-forming, non-motile rods that formed offwhite/pale yellow colonies within 2-4 days on nutrient agar (lacking $\mathrm{NiCl}_{2}$ ). The colonies formed were circular, entire, convex and shiny in appearance. The optimum growth temperature for strain $\mathrm{Y}^{8} 8^{\mathrm{T}}$ was $30^{\circ} \mathrm{C}$; growth was observed at $25-35{ }^{\circ} \mathrm{C}$ but not at $37{ }^{\circ} \mathrm{C}$.

Total genomic DNA was extracted as described by Tiirola et al. (2002); total RNA was isolated using an RNAextraction kit according to the instruction of the manufacturer (Qiagen). The 16S rRNA gene was analysed as described by Lane (1991) and the sequence determined 
using an ABI 3100 sequencer (Applied Biosystems). 16S rRNA gene sequence alignments were performed using the CLUSTAL_X program (Thompson et al., 1997). A phylogenetic tree was constructed using the neighbour-joining method with bootstrap values based on 1000 replicates (Saitou \& Nei, 1987). To determine the cellular fatty acid profile, cells were grown in nutrient broth (containing, $1^{-1}$, $3.0 \mathrm{~g}$ beef extract and $5.0 \mathrm{~g}$ peptone) and harvested in the late exponential phase; whole-cell fatty acid methyl esters were prepared and analysed commercially (MIDI Inc.) and polyamines were extracted and analysed as described by Busse \& Auling (1988) and Busse et al. (1997).

Indirect evidence for diazotrophy in $\mathrm{Y} 88^{\mathrm{T}}$ was obtained by demonstrating sustained growth in nitrogen-limited minimal medium (containing, $\mathrm{I}^{-1}, 0.4 \mathrm{~g} \quad \mathrm{KH}_{2} \mathrm{PO}_{4}, 0.1 \mathrm{~g}$ $\mathrm{K}_{2} \mathrm{HPO}_{4}, 0.2 \mathrm{~g} \mathrm{MgSO}_{4}, 0.1 \mathrm{~g} \mathrm{NaCl}, 10 \mathrm{mg} \mathrm{FeCl}, 2 \mathrm{mg}$ $\mathrm{Na}_{2} \mathrm{MoO}_{4}, 5 \mathrm{~g}$ glucose, $50 \mathrm{mg}$ yeast extract and $0.1 \mathrm{~g}$ $\mathrm{NH}_{4} \mathrm{Cl} ; \mathrm{pH} 7.2 \pm 0.1$ ) concomitant with the detection of a positive acetylene-reduction assay (Sprent \& Sprent, 1990), and by the detection of a nifH gene (encoding the iron protein of nitrogenase, a key enzyme in nitrogen fixation) in $\mathrm{Y}^{\mathrm{T}}{ }^{\mathrm{T}}$ through the amplification of a $360 \mathrm{bp} \mathrm{nifH}$ fragment (with primers PolF and PolR) as described by Poly et al. (2001).

During growth on nitrogen-limited minimal medium with glucose as the sole carbon source, $\mathrm{Y} 88^{\mathrm{T}}$ accumulated polyhydroxyalkanoate granules up to a level of $41 \pm 16 \%$ dry cell weight. The polyhydroxyalkanoate was composed of hydroxy-aliphatic esters of 3-hydroxybutyric acid and was extracted and analysed by gas chromatography using the method described by Riis \& Mai (1988) to confirm the monomer composition. To visualize the granules, bacteria containing polyhydroxyalkanoate were centrifuged to a pellet, embedded in agar (2\%), fixed in glutaraldehyde ( $2 \%$ in cacodylate buffer), dehydrated in an acetone series and embedded in Spurr's resin. Ultrathin $120 \mathrm{~nm}$ sections were prepared with a diamond knife and mounted on copper support grids. Sections were stained with uranyl acetate/lead citrate and examined in a JEOL 6700 field emission scanning electron microscope using a transmission detector (see Supplementary Fig. S1 available in IJSEM Online).

The results of Microbact 24E and oxidase tests (Oxoid) showed that $\mathrm{Y} 88^{\mathrm{T}}$ was positive for catalase, nitrate reductase and urease activities and negative for arginine dehydrogenase activity. $\mathrm{Y}^{8} 8^{\mathrm{T}}$ was negative for indole production, acid production from glucose and assimilation of citrate, sorbitol, inositol, rhamnose, malonate, lactose, adonitol, raffinose and arabinose. Additional features that serve to differentiate strain $\mathrm{Y} 88^{\mathrm{T}}$ from recognized members of the genus Novosphingobium are shown in Table 1.

The predominant fatty acids of $\mathrm{Y}^{\mathrm{T}} 8^{\mathrm{T}}$ were $18: 1 \omega 7 \mathrm{c}$ $(58.4 \%)$ and $16: 1 \omega 7 c(17.1 \%)$, and, consistent with

Table 1. Differential characteristics of strain $\mathrm{Y}^{8} 8^{\top}$ from other Novosphingobium species

Strains: 1, Y88 ${ }^{\mathrm{T}} ; 2$, N. aromaticivorans SMCC F199 $;$; N. Napsulatum ATCC $14666^{\mathrm{T}} ; 4$, N. hassiacum DSM 14552 ${ }^{\mathrm{T}} ; 5, \mathrm{~N}^{\mathrm{T}}$ rosa IFO $15208^{\mathrm{T}}$; 6, N. stygium ATCC $700280^{\mathrm{T}} ; 7$, N. subarcticum HAMBI $2110^{\mathrm{T}} ; 8$, N. subterraneum DSM $12447^{\mathrm{T}}$; 9, N. tardaugens JCM $11434^{\mathrm{T}}$; 10 , N. pentaromativorans KCTC $10454^{\mathrm{T}} ; 11$, N. lentum DSM $13663^{\mathrm{T}} ; 12$, N. taihuense JCM $12465^{\mathrm{T}}$. Data for strains 4-12 were taken from Liu et al. (2005). + , Positive; -, negative; $(+)$, weakly positive; ND, not determined. All strains were positive for catalase and nitrate reduction. All strains were negative for arginine dehydrolase, oxidase, indole production, acid production from glucose, denitrification and for assimilation of adonitol, citrate, D-mannitol, D-sorbitol, L-alanine and L-phenylalanine.

\begin{tabular}{|c|c|c|c|c|c|c|c|c|c|c|c|c|}
\hline Characteristic & 1 & 2 & 3 & 4 & 5 & 6 & 7 & 8 & 9 & 10 & 11 & 12 \\
\hline \multicolumn{13}{|l|}{ Assimilation of: } \\
\hline$N$-Acetyl-D-glucosamine & + & + & + & - & $(+)$ & - & + & - & - & - & - & - \\
\hline D-Cellobiose & + & + & + & + & + & - & - & + & - & - & - & + \\
\hline D-Galactose & + & - & + & - & - & - & + & - & - & - & - & - \\
\hline D-Glucose & + & + & + & + & + & - & + & + & - & - & - & + \\
\hline D-Mannose & + & + & $(+)$ & - & + & - & - & + & - & - & - & + \\
\hline Maltose & + & + & + & - & + & - & + & + & - & - & - & + \\
\hline D-Melibiose & - & - & - & - & + & - & - & + & - & - & - & - \\
\hline L-Rhamnose & - & + & + & - & + & - & + & + & - & + & - & + \\
\hline Sucrose & + & + & + & + & + & - & - & + & - & + & - & + \\
\hline Trehalose & + & - & + & - & - & - & - & - & - & + & - & - \\
\hline$\beta$-Galactosidase & - & + & + & - & + & + & + & + & - & - & - & $\mathrm{ND}$ \\
\hline Gelatin hydrolysis & - & - & + & - & - & - & - & + & - & - & - & - \\
\hline
\end{tabular}


recognized Novosphingobium species, the only hydroxy fatty acid present was 2-OH 14:0 (15.1\%). Smaller quantities of $16: 0(4.3 \%)$ and $17: 1 \omega 6 c(3.0 \%)$ fatty acids were present. The fatty acid profile of $\mathrm{Y}^{\mathrm{T}} 8^{\mathrm{T}}$ shares the same major 18:1 and 16:1 fatty acid classes as the recognized Novosphingobium species (Liu et al., 2005; Tiirola et al., 2005). $\mathrm{Y}^{8} 8^{\mathrm{T}}$ contained spermidine as the only polyamine compound, clearly differentiating this strain from Sphingomonas sensu stricto (Takeuchi et al., 2001).

Alignment of the $16 \mathrm{~S}$ rRNA gene sequence of strain $\mathrm{Y} 88^{\mathrm{T}}$ with those of members of the genus Novosphingobium confirmed the presence of the Novosphingobium signature nucleotides (52C, 134G, 359G, 593U, 987G, 990U, 1215A and 1218C; Takeuchi et al., 2001) in the isolate. Direct alignments of the $16 \mathrm{~S}$ rRNA gene sequence of strain $\mathrm{Y} 88^{\mathrm{T}}$ showed that the highest level of sequence identity occurred with respect to $N$. stygium ATCC $700280^{\mathrm{T}}$ (96\% over $1190 \mathrm{bp}$ ); however, the complete sequence (1423 bp) of $\mathrm{Y}_{8} 8^{\mathrm{T}}$ showed a lower percentage identity with respect to other Novosphingobium species because of a 21 bp gap in the $\mathrm{Y}^{2} 8^{\mathrm{T}} 16 \mathrm{~S}$ rRNA gene sequence commencing at base number $1192\left(\mathrm{Y}^{\mathrm{T}} 8^{\mathrm{T}}\right.$ numbering). The presence of this gap in the $\mathrm{Y} 88^{\mathrm{T}} 16 \mathrm{~S}$ rRNA gene sequence was confirmed by repeat sequencing of the $16 \mathrm{~S}$ rRNA PCR products from independent preparations of $\mathrm{Y}^{\mathrm{T}} 8^{\mathrm{T}} \mathrm{DNA}$ and by sequencing of DNA copies made from rRNA by reverse transcription from $\mathrm{Y}^{8} 8^{\mathrm{T}}$ RNA extracts. The $16 \mathrm{~S}$ rRNA gene sequence from N. capsulatum ATCC $14666^{\mathrm{T}}$ was used as a control sequence (i.e. one that does not contain this deletion). The gap present in the $\mathrm{Y} 88^{\mathrm{T}} 16 \mathrm{~S}$ rRNA gene sequence represents a potential signature region by which $\mathrm{Y} 88^{\mathrm{T}}$ could be distinguished from recognized Novosphingobium species and sphingomonads. The complete $16 \mathrm{~S}$ rRNA gene sequence of $\mathrm{Y}^{2} 8^{\mathrm{T}}$ most closely matched those of $N$. stygium ATCC $700280^{\mathrm{T}}(94.7 \%)$ and $N$. taihuense JCM $12465^{\mathrm{T}}$ $(94.5 \%)$. The neighbour-joining tree constructed on the basis of the 16S rRNA gene sequences (Fig. 1) indicated that the closest relative of $\mathrm{Y}^{\mathrm{T}} 8^{\mathrm{T}}$ was $N$. stygium ATCC $700280^{\mathrm{T}}$.

Analysis of the partial sequence (319 bp minus the primer regions) of the nifH gene of $\mathrm{Y} 8^{\mathrm{T}}$ revealed that the sequence was $89 \%$ identical to those obtained from uncultured bacteria (GenBank accession nos AF389709 and AF389707); lower levels of sequence identity were found for nifH sequences derived from species with validly published names. Recently, Xie \& Yokota (2006) described Sphingomonas azotifigens as the first diazotrophic type strain belonging to the genus Sphingomonas. The nifH sequences of $\mathrm{Y}_{8} 8^{\mathrm{T}}$ and S. azotifigens are $88.4 \%$ identical (98\% for the corresponding amino acid sequence).

Sphingomonads have not been investigated extensively with respect to diazotrophy, or with respect to their ability to the storage polymer polyhydroxyalkanoate: therefore, it is not known how widespread these properties may be throughout this group. Examples of polyhydroxyalkanoateaccumulating sphingomonads include three strains of Sphingopyxis and Sphingomonas that have been shown to accumulate a polyhydroxyalkanoate content of up to $70 \%$ (Godoy et al., 2003). Such properties are unlikely to be unique to strain $\mathrm{Y}^{2} 8^{\mathrm{T}}$, and, as sphingomonads are often isolated from low-nitrogen, high-carbon environments, diazotrophic sphingomonads are expected to be more common than is currently realized. To our knowledge, $\mathrm{Y} 88^{\mathrm{T}}$ is the first type strain described as belonging to the genus Novosphingobium and capable of both diazotrophy and polyhydroxyalkanoate synthesis.

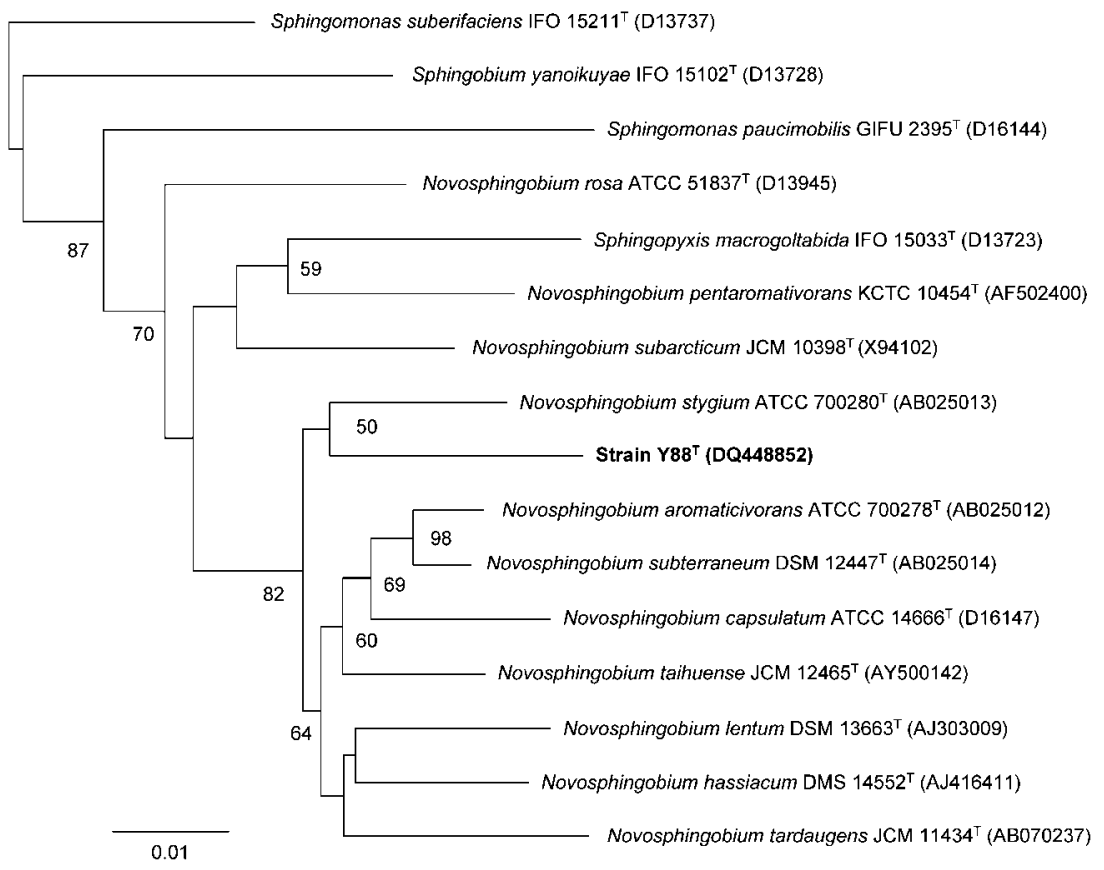

Fig. 1. Neighbour-joining phylogenetic tree, based on 16S rRNA gene sequences, for strain $Y 88^{\top}$ and related taxa. The final analysis included 1377 bp; gaps and alignment uncertainties were omitted from the analysis. Numbers at nodes indicate percentages of bootstrap support (based on 1000 replicates); only values greater than $50 \%$ are shown. Sphingomonas suberifaciens IFO $15211^{\top}$ was used as the outgroup. Bar, evolutionary distance $\left(K_{\text {nuc }}\right)$ of 0.01 . 
Three distinguishing features described by Takeuchi et al. (2001) can be used to differentiate Sphingomonas sensu stricto, Sphingobium, Novosphingobium and Sphingopyxis. These include hydroxy fatty acid profiles, polyamine patterns and nitrate reduction. Members of the genera Sphingobium and Novosphingobium contain 2-OH 14:0 as the only 2-hydroxy fatty acid (Takeuchi et al., 2001), although this is somewhat variable for different growth media (Yabuuchi et al., 2002). The predominant polyamine in Sphingomonas sensu stricto is sym-homospermidine, whereas members of the Novosphingobium, Sphingobium and Sphingopyxis clusters lack sym-homospermidine but contain spermidine as the main polyamine compound. Nitrate reduction was typical only for members of the Sphingobium and Novosphingobium clusters. $\mathrm{Y}^{\mathrm{T}} 8^{\mathrm{T}}$ contains 2-OH 14:0 as the major 2-hydroxy fatty acid component, has spermidine as the major polyamine and possesses nitrate reductase activity. These biochemical and chemotaxonomic data support the designation of $\mathrm{Y} 88^{\mathrm{T}}$ as a member of the Novosphingobium cluster. Takeuchi et al. (2001) described $\beta$-galactosidase activity (which is absent from $\mathrm{Y} 88^{\mathrm{T}}$ ) as a phenotypic marker for the members of the Novosphingobium cluster; however, recently described Novosphingobium species ( $N$. hassiacum, N. tardaugens, $N$. pentaromativorans and $N$. lentum) were also found to be negative for $\beta$-galactosidase activity.

From our polyphasic analysis of genotypic, phenotypic and chemotaxonomic traits we conclude that the following defining features indicate that strain $\mathrm{Y}^{2} 8^{\mathrm{T}}$ represents a novel species of the genus Novosphingobium: 16S rRNA gene sequence identities below $95 \%$, a 21 bp signature gap in the $\mathrm{Y} 88^{\mathrm{T}} 16 \mathrm{~S}$ rRNA gene sequence and a positive result for urease activity. The name Novosphingobium nitrogenifigens sp. nov. is proposed for strain $\mathrm{Y} 88^{\mathrm{T}}$.

\section{Description of Novosphingobium nitrogenifigens sp. nov.}

Novosphingobium nitrogenifigens (ni.tro.gen.i' fi.gens. N.L. n. nitrogenum nitrogen; L. part. adj. figens fixing; N.L. part adj. nitrogenifigens referring to the ability of this organism to fix nitrogen).

Cells are Gram-negative, aerobic, non-spore-forming, nonmotile rods. Colonies produced after 2-4 days cultivation on nutrient agar are off-white/pale yellow, circular, entire, convex and shiny. Growth is observed at $15-35{ }^{\circ} \mathrm{C}$ but not at $37{ }^{\circ} \mathrm{C}$; the optimum growth temperature is $30^{\circ} \mathrm{C}$. Nitrogen-fixing occurs and polyhydroxyalkanoate granules are accumulated. Positive for catalase, nitrate reductase and urease, but negative for arginine dehydrogenase and $\beta$ galactosidase. Negative for indole production, acid production from glucose and assimilation of citrate, sorbitol, inositol, rhamnose, malonate, lactose, adonitol, raffinose and arabinose. The predominant fatty acid is $18: 1 \omega 7 c$ $(58.4 \%)$ and the major hydroxylated fatty acid is $2-\mathrm{OH}$ $14: 0(15.1 \%)$. The fatty acid profile also contains $16: 1 \omega 7 c$ $(17.1 \%), 16: 0(4.3 \%)$ and $17: 1 \omega 6 c(3.0 \%)$. Contains spermidine as the only polyamine. The $16 \mathrm{~S}$ rRNA gene sequence of the strain matches the specific nucleotide signature bases for the genus Novosphingobium, as described by Takeuchi et al. (2001), and contains a 21 bp gap starting at base $1192\left(\mathrm{Y}^{2} 8^{\mathrm{T}}\right.$ numbering) when aligned with other Novosphingobium species.

The type strain, $\mathrm{Y} 88^{\mathrm{T}}\left(=\mathrm{ICMP} 16470^{\mathrm{T}}=\mathrm{DSM} 19370^{\mathrm{T}}\right)$, was isolated from pulp and paper wastewater in New Zealand.

\section{Acknowledgements}

This work was supported by the New Zealand Foundation for Research Science and Technology. We thank Professor Hans G. Trüper for help with naming of the novel species. We also thank Anne-Marie Smit, Quanfeng Liang and Hank Kroese for their technical assistance.

\section{References}

Balkwill, D. L., Drake, G. R., Reeves, R. H., Fredrickson, J. K., White, D. C., Ringelberg, D. B., Chandler, D. P., Romine, M. F., Kennedy, D. W. \& Spadoni, C. M. (1997). Taxonomic study of aromaticdegrading bacteria from deep-terrestrial-subsurface sediments and description of Sphingomonas aromaticivorans sp. nov., Sphingomonas subterranea sp. nov., and Sphingomonas stygia sp. nov. Int J Syst Bacteriol 47, 191-201.

Busse, H.-J. \& Auling, G. (1988). Polyamine pattern as a chemotaxonomic marker within the Proteobacteria. Syst Appl Microbiol 11, $1-8$.

Busse, H.-J., Bunka, S., Hensel, A. \& Lubitz, W. (1997). Discrimination of members of the family Pasteurellaceae based on polyamine patterns. Int J Syst Bacteriol 47, 698-708.

Fujii, K., Satomi, M., Morita, N., Motomura, T., Tanaka, T. \& Kikuchi, S. (2003). Novosphingobium tardaugens sp. nov., an oestradioldegrading bacterium isolated from activated sludge of a sewage treatment plant in Tokyo. Int J Syst Evol Microbiol 53, 47-52.

Godoy, F., Vancanneyt, M., Martínez, M., Steinbüchel, A., Swings, J. \& Rehm, B. H. A. (2003). Sphingopyxis chilensis sp. nov., a chlorophenol-degrading bacterium that accumulates polyhydroxyalkanoate, and transfer of Sphingomonas alaskensis to Sphingopyxis alaskensis comb. nov. Int J Syst Evol Microbiol 53, 473-477.

Kämpfer, P., Witzenberger, R., Denner, E. B. M., Busse, H.-J. \& Neef, A. (2002). Novosphingobium hassiacum sp. nov., a new species isolated from an aerated sewage pond. Syst Appl Microbiol 25, 37-45.

Lane, D. J. (1991). 16S/23S rRNA sequencing. In Nucleic Acid Techniques in Bacterial Systematics, pp. 115-175. Edited by E. Stackebrandt \& M. Goodfellow. Chichester: Wiley.

Leifson, E. (1962). The bacterial flora of distilled and stored water. III. New species of the genera Corynebacterium, Flavobacterium, Spirillum, and Pseudomonas. Int Bull Bacteriol Nomencl Taxon 12, 161-170.

Liu, Z.-P., Wang, B.-J., Liu, Y.-H. \& Liu, S.-J. (2005). Novosphingobium taihuense sp. nov., a novel aromatic-compound-degrading bacterium isolated from Taihu Lake, China. Int J Syst Evol Microbiol 55, 1229-1232.

Nohynek, L. J., Nurmiaho-Lassila, E.-L., Suhonen, E. L., Busse, H.-J., Mohammadi, M., Hantula, J., Rainey, F. \& Salkinoja-Salonen, M. S. (1996). Description of chlorophenol-degrading Pseudomonas sp. strains $\mathrm{KF}^{\mathrm{T}}, \mathrm{KF} 3$, and $\mathrm{NKF} 1$ as a new species of the genus Sphingomonas, Sphingomonas subarctica sp. nov. Int J Syst Bacteriol 46, 1042-1055. 
Poly, F., Monrozier, L. J. \& Bally, R. (2001). Improvement in the RFLP procedure for studying the diversity of nifH genes in communities of nitrogen fixers in soil. Res Microbiol 152, 95-103.

Riis, V. \& Mai, W. (1988). Gas chromatographic determination of polybeta-hydroxybutyric acid in microbial biomass after hydrochloric acid propanolysis. J Chromatogr 445, 285-289.

Saitou, N. \& Nei, M. (1987). The neighbour-joining method: a new method for reconstructing phylogenetic trees. Mol Biol Evol 4, 406-425.

Sohn, J. H., Kwon, K. K., Kang, J.-H., Jung, H.-B. \& Kim, S.-J. (2004). Novosphingobium pentaromativorans sp. nov., a high-molecular-mass polycyclic aromatic hydrocarbon-degrading bacterium isolated from estuarine sediment. Int J Syst Evol Microbiol 54, 1483-1487.

Sprent, J. I. \& Sprent, P. (1990). Nitrogen Fixing Organisms: Pure and Applied Aspects, 2nd edn. London \& New York: Chapman Hall.

Takeuchi, M., Sawada, H., Oyaizu, H. \& Yokota, A. (1994). Phylogenetic evidence for Sphingomonas and Rhizomonas as nonphotosynthetic members of the alpha- 4 subclass of the Proteobacteria. Int $J$ Syst Bacteriol 44, 308-314.

Takeuchi, M., Sakane, T., Yanagi, M., Yamasato, K., Hamana, K. \& Yokota, A. (1995). Taxonomic study of bacteria isolated from plants: proposal of Sphingomonas rosa sp. nov., Sphingomonas pruni sp. nov., Sphingomonas asaccharolytica sp. nov. and Sphingomonas mali sp. nov. Int J Syst Bacteriol 45, 334-341.

Takeuchi, M., Hamana, K. \& Hiraishi, A. (2001). Proposal of the genus Sphingomonas sensu stricto and three new genera, Sphingobium, Novosphingobium and Sphingopyxis, on the basis of phylogenetic and chemotaxonomic analyses. Int J Syst Evol Microbiol 51, 1405-1417.
Thompson, J. D., Gibson, T. J., Plewniak, F., Jeanmougin, F. \& Higgins, D. G. (1997). The CLUSTAL_X Windows interface: flexible strategies for multiple sequence alignment aided by quality analysis tools. Nucleic Acids Res 25, 4876-4882.

Tiirola, M. A., Wang, H., Paulin, L. \& Kulomaa, M. S. (2002). Evidence for natural horizontal transfer of the $p c p B$ gene in the evolution of polychlorophenol-degrading Sphingomonads. Appl Environ Microbiol 68, 4495-4501.

Tiirola, M. A., Busse, H.-J., Kämpfer, P. \& Männistö, M. K. (2005). Novosphingobium lentum sp. nov., a psychrotolerant bacterium from a polychlorophenol bioremediation process. Int J Syst Evol Microbiol 55, 583-588.

Xie, C.-H. \& Yokota, A. (2006). Sphingomonas azotifigens sp. nov., a nitrogen-fixing bacterium isolated from the roots of Oryza sativa. Int J Syst Evol Microbiol 56, 889-893.

Yabuuchi, E., Yano, I., Oyaizu, H., Hashimoto, Y., Ezaki, T. \& Yamamoto, H. (1990). Proposals of Sphingomonas paucimobilis gen. nov. and comb. nov., Sphingomonas parapaucimobilis sp. nov., Sphingomonas yanoikuyae sp. nov., Sphingomonas adhaesiva sp. nov., Sphingomonas capsulata comb. nov., and two genospecies of the genus Sphingomonas. Microbiol Immunol 34, 99-119.

Yabuuchi, E., Kosako, Y., Fujiwara, N., Naka, T., Matsunaga, I., Ogura, H. \& Kobayashi, K. (2002). Emendation of the genus Sphingomonas Yabuuchi et al. 1990 and junior objective synonymy of the species of three genera, Sphingobium, Novosphingobium and Sphingopyxis, in conjunction with Blastomonas ursincola. Int J Syst Evol Microbiol 52, 1485-1496. 